\title{
The effect test of the mediation between specific psychosocial hazards on elementary teachers' job demands and their work well-being
}

\section{Introduction}

The pursuit of "happiness" has always been a primary goal of people's lives. Since late 1950s, the study of sense of happiness has been used in many developed countries as an indicator of the quality of life (Keyes, Shmotkin \& Ryff, 2002). Among workers of different walks, teachers are extremely sensitive to stress from their teaching work, more so than people of other working classes (Çokluk, 2003). Quite often they feel burned-out, unhappy, dull, or dissatisfied with current life (Ilgan, Özü-Cengiz, Ata \& Akram, 2015). Such a tendency occurs to educators at different stages of education. Teachers of all levels are reported to be in situations of low well-being (Başol \& Altay, 2009; Kırılmaz, Çele \& Sarp, 2003). Some literature argues that positive psychology should be closely related to the working environment, quality of working life, or job satisfaction. It is also noted that "healthy work" can enhance psychological and physiological well-being (Al-Qutop \& Harrim, 2011; Ilgan et al., 2015). It is obvious that the environment of life and work has an important impact on people's mental health and the sense of happiness that comes with it. This is a topic worthy of more attention and begging for further investigation.

Kyriacou (2001) believes that teachers are currently one of the most stressful occupations. Due to the particularity of their roles and the professionalism demanded from them to contribute to the success of education, teachers are always under a lot of stress. Hean \& Garrett (2001) pointed out that the happier the teachers, the more qualified they are. The teachers who are happy with their teaching jobs are more equipped to find satisfaction in the efficiency and effectiveness of teaching, to initiate better interaction between teachers and students, and to help students to build self-confidence and optimism. They are also better equipped to deal with challenging conflicts between teachers and parents, and stressful confrontations between teachers and students. Yildirim (2015) also pointed out that the main determinants of teachers' professional well-being are self-efficacy, job satisfaction and recognition. Since the education reforms for the past ten years in Taiwan have prompted teachers to have their classrooms open to the public for visiting tours and the schools to encourage more frequent parent-teacher communication, teachers are forced to deal with more personal interactions and thus endure more emotional impacts from being under scrutiny all the time. If teachers are able to have their communications and interactions with students' parents under control and adjust well to emotional ups and downs, they should have no difficulty in upholding their passion for teaching and fulfil their work well-being (Ilgan et al., 2015). For a happy teacher with a sense of happiness in the teaching job, education is a contribution rather than a sacrifice; education is not tedious repetition, but a creative work; education is not just a means for making a living, but is life itself (Al-Qutop \& Harrim, 2011). 
With the rapid changes in the society and the enormous advancement in information technology, policies in education continue to evolve. On the other hand, with the impact of decades of declining birthrate in Taiwan, many schools are forced to adjust their policies to great challenges such as coping with school low enrollment rate, reducing students' urban-rural achievement gaps, utilizing idle spaces, eliminating waste of resources, improving students' learning quality, solving redundancy in teaching workforce and worrying about possible layoff (Lin, 2006). Under the drastic policy and structure changes in education system, Taiwan's elementary school teachers have endured an antagonizing amount of stress and pressure. The Ministry of Education (2012) revealed in the White Paper on Teacher Cultivation in the Republic of China: "Education is the key to the country's future prosperity; the quality of education is in the hand of great teachers." In other words, the success in education depends greatly on how educators perform their jobs and how stable their emotion is. Teachers are the backbone of a school's education. We can only expect teachers who are sensitive to human health and well-being to educate students well. This is why the current study aims to look into teachers' work well-being and how significant such a line of investigation is. The International Labor Organization (ILO, 2000) pointed out in their survey report that in every developed country in Europe and America, one in ten employees suffers from depression, anxiety, work stress or burnout; and in the past ten years, advances in technology, globalization, organizational restructuring, ever-changing corporate policies, and increasing job demands and job insecurity are causing workers a great deal of stress in the workplace. It is evident that erratic changes in the working environment will certainly affect the psychological and physical health of individual employees.

In 2010, Institute of Labor, Occupational Safety and Health, Ministry of Labor, conducted a survey of more than 17,000 workers on the workplace conditions, showing that 13 out of every 100 workers were under great pressure at work. Since this number is about twice as large as that in 1994, it indicates that the work pressure for Taiwan's workforce is getting more and more serious (Institute of Labor, Occupational Safety and Health, Ministry of Labor, 2011). An unhealthy workplace without good pressure management will not only cause negative impacts on individuals, such as physical and psychological illness, lack of positive incentives and lower quality at work, but also have a great impact on the development of the organization. Therefore, creating a healthy and safe working environment should be the least that every worker would hope for (Li, Chen \& Chen, 2006). In the past decades, research has found that stress, anger, resentment, anxiety, and upset are all detrimental to human health (Baumgardner \& Crothers, 2009). Similarly, when teachers' workload and burden are getting heavier, they become easily tired of their work, their health will be deteriorating, and they gradually lose their passion for teaching. This is typical of fatigue and job burnout. Once teachers suffer from job burnout, they not only lose their enthusiasm in teaching, but also hesitate or feel reluctant to put efforts and energy in caring for students' learning and welfare, which will seriously affect their teaching 
effectiveness. This is a great loss to the students and certainly a great loss to the education community. Therefore, the researchers believe that it is necessary for us to further understand the relationship between the work pressure and job burnout suffered by the elementary school teachers and their well-being at work.

Researchers believe that high stress is negatively related to several domains of well-being (Romano \& Wahlstrom, 2000). Due to the particularity of their roles and the professionalism demanded from them to contribute to the success of education, teachers are always under a lot of stress. If teachers feel a strong sense of work well-being, they will certainly bring more joy and happiness to students. Therefore, we must care more about teachers' sense of well-being. Only through reducing teachers' workload and pressure and by enhancing their work well-being can we expect teachers to cultivate outstanding and happy talents of the country. Consequently, our education authorities and institutes should focus their efforts on how to improve teachers' work well-being and realize the lofty goals of education justice and equality.

\section{Literature review}

\section{Work well-being and related studies}

The study of well-being was first started in the 1950s. Traditional research on well-being can be categorized into two lines of study: subjective well-being (SWB) and psychological well-being (PWB). Although subjective well-being and psychological well-being are not entirely different, they are similar but take different approaches in explaining how positive psychology operates on the mind of individuals. Subjective well-being is regarded as the overall evaluation of an individual's emotions and quality of life, whereas psychological well-being emphasizes the potential of an individual to pursue meaningful life and self-realization under the challenge of day-to-day life (Keyes, Shmotkin, \& Ryff, 2002). Starting from the end of the twentieth century, in the Western psychology community, there has been a great interest in the study of positive psychology. Scholars began to work on how to define and differentiate the terms "happiness" and "well-being".

Wilson (1967) first mentioned that although subjective well-being is similar to happiness, they are not exactly the same. Happiness is considered to be one of the evaluations of subjective well-being. Diener (1984) believes that well-being is the result of an assessment of life, and life satisfaction can represent an individual's assessment of the overall quality of life, that is, the degree of personal well-being. In their study of subjective well-being, Keyes \& Magyar-Moe (2003) mentioned that subjective well-being includes awareness of happiness and social life satisfaction, positive and negative emotional balance, psychological well-being and social wellbeing. Carruthers \& Hood (2004) believes that "well-being" means a concept that is often 
associated with happiness, optimism, energy, self-fulfillment, self-fulfillment, self-acceptance, purposeful life, ideal operation and life satisfaction. Diener, Lucas \& Oishi (2005) argue that subjective well-being is a set of individual's evaluations of cognitive and emotional life. These evaluations include positive and negative emotions, as well as cognitive assessments of life satisfaction. Meanwhile, Luo \& Luo (1998) also believes that the so-called "subjective wellbeing" is a contemplative evaluation of the quality of life. It is a subjective feeling that includes highly positive emotions and a subjective perception of overall satisfaction with life. Lai (2005) also pointed out that good psychological well-being indicators must have the following four components: 1 . Consisting of positive and negative contributing factors of psychological wellbeing; 2. Having concrete and operable well-being indicators 3. Based on personal and subjective perception and interpretation; 4. Being aware that psychological well-being is relative, not absolute. Bricheno, Brown \& Lubansky (2009) argue that teachers' well-being might be influenced by the following nine factors: how much is the teaching load, able or not able to control their work, with or without support, how much is the impact of changes, whether their role is clear, the impact of the population, comparison with other groups, interfering policies and students' achievement. Green, Felstead, Gallie \& Inanc (2013), for the first time, explored the work well-being of the British workers from the skills and employment point-ofview: 1. A slight decline was shown on the enthusiasm scale, while a significant decline was seen on the contentment scale; 2 . Only men showed a decline on the enthusiasm scale, largely due to low education achievements; 3 . Main reasons for the decline: the sense of insecurity is rising, the work is too pressing (work intensification), the organization is often downsizing, etc.; 4. Work pressure is building up significantly, while job satisfaction is declining. Sarath \& Manikandan (2014)'s research findings on school teachers' work commitment and work wellbeing show that healthy school teachers and work well-being as well as overall work commitment are clearly positively correlated.

There are many studies on the well-being and satisfaction of teachers in Taiwan, but most of them cover the "whole" well-being, lacking the specificity of work or workplace. The recent relevant research of work well-being abroad has been focused on the definitions of terminology, mainly concerning about work well-being or workplace happiness.

\section{Psychosocial hazards on teachers}

Job demands refer to the physical, psychological, social, and organizational aspects of work that continue to require physical, cognitive and emotional efforts to endure the load and strive to complete the job. It is easy to see job demands have a negative impact on the worker, physically and psychologically. High work pressure, role overload, poor work environment, and organization restructuring are cases of detrimental work demands. (Demerouti, Bakker, Nachreiner \& Schaufeli, 2001; Mulholland, McKinlay \& Sproule, 2013). Excessive job demands or job overload can also exhaust the mental and physical strength of employees, 
leading to energy exhaustion and other health problems (Al-Ghamdi, 2017; Demerouti et al., 2013). However, different work situations can result in different levels of job demands. For instance, more job requirements demanded from workers will certainly bring them more fatigue and feel more exhausted (Cordes \& Dougherty, 1993). Job demands usually refer to the parts that demands of mental burnouts, usually associated with specific physical and psychological costs (Demerouti et al., 2001), such as role ambiguity, role conflicts, workload, work stress, struggling from work and family conflicts, poor working environment and organization restructuring (Lee \& Ashforth, 1996), which will certainly have a negative impact on the physical and psychological health. In order to accomplish a great number of teaching requirements under the pressure of limited time and in a noisy work environment, teachers must hide their emotions or adjust themselves to the stress, deal with problems put forth by students and parents, and sometimes struggle to find balance between work and family when there are schedule conflicts or priority problems. When the teachers cannot find opportunities to have enough rest, they are doomed to be under the pressure of time and the job demands are sure to stretch them out physically and mentally. This study explores the issue of job demands from two dimensions: "workload demands" and "emotional demands". They are described as follows:

\section{Workload demands}

Job demands are usually reflected in workload, workload demands in particular (Zhang, Yan \& Huang, 2011), especially when workload is one of the major sources of work stress (Lu, 1997; Cooper et al., 2001). In past studies of the facets affecting the level of teacher's work stress, the results showed that "workload" or "time management" has the greatest impact. That is, the greater the workload, the greater the teacher's work pressure. The studies also found that the teachers who work concurrently as an administer or as advisory are typically under extreme pressure (Zhou \& Peng, 2005; Ke \& Lin, 2006; Dai \& He, 2006). Bakker, Demerouti \& Euwema (2005) conducted a study on the relationship between job demands and job burnout. The data collected from 1,012 Dutch high-level vocational education faculty members showed that work overload, emotional demands, physiological demands, work-family conflicts and other factors have a positive impact on job burnout. Hakanen, Bakker \& Schaufeli (2006) also studied the relationship between job demands and job burnout of 2,038 Finnish teachers. They found that workload, student misconduct, and poor working environment also had a positive impact on job burnout.

\section{Emotional demands}

Emotional labor was first proposed by Hochschild (1983), who defined emotional labor as "the management of feeling at work by workers who are in frequent contact with customers, in order to create a publicly observable facial and bodily display. In compliance with the organization's regulations and salary compensation systems, these workers must control their 
personal emotions well in the workplace so that they can fit in the work atmosphere that the organization wants to create." Hochschild (1993) once again redefines the emotional labor as "understanding, assessing and managing emotions, including the emotions of others (customers, coworkers) and their own authority." Long-term emotional labor will cause selfalienation between teachers' genuine inner feelings and emotional labor. It might lead to job burnout and personal emotional exhaustion (Wu \& Zheng, 2003). Grandey (2000) argues that emotional labor is closely related to job burnout and work stress; Sandiford \& Seymour (2002) confirms that certain evidence of emotional labor will lead to work stress, and emotional labor is predictive of job burnout and emotional exhaustion ( Li \& Chen, 2006; Näring et al., 2006).

\section{The psychosocial hazard factors of teaching}

\section{Noise and voice strain}

The damage done by noise is multi-faceted. Noise not only causes great interference to people's normal life and work, but also affects people's conversation, thinking and sleep by causing irritability, slow response, reduction of work efficiency, distraction of people's attention, and accidents at work. The more serious situation is that noise can damage people's hearing and health (Guo, 2005). The impact of noise pollution is greater on people doing mental work than those performing physical labor. The impact on those who have to do a lot of memorization, thinking, or decision-making is even more profound (Eschricht et al., 2009). Dong (2001) pointed out that the volume of lecturing given by elementary school teachers increased with the background noise of the classroom and that the background noise of the classroom caused many teachers to form a bad habit of raising their voice while speaking. Chen, Wei \& Wu (2004) used the primary schools of five different architecture layouts in Annan District of Tainan City as an example. Using decibel meters to do on-site acoustic measurement, it was found that most of the loudest noise heard on campus was from the traffic outside the school or the factory in residential area that is next door to the school. The loud sound of car horns and emergency sirens have the most serious impact on the campus. The effect is different for different layouts of school buildings. If an enclosed campus is surrounded by school buildings, the noise will be kept inside the school with no way out. As a result, it will become a source of noise pollution within the campus itself. In order to speak louder than the noise background, teachers are forced to raise their voice in a noisy environment, which in turn becomes a bad habit of the teacher's speaking and even results in symptoms such as having difficulty in speaking or having hoarse voice (Dong, 2001).

\section{Lesson disturbances}

Hakanen, Bakker \& Schaufeli (2006) used the Job Demands-Resources model (JD-R) 
to study how job burnout and work commitment of 2,038 Finnish teachers influenced teachers' health and organizational commitment. Among the sampling subjects, $82 \%$ of them are at the age of 26-55, their average length of teaching is 13.5 years, and the average working time per week is 36.6 hours. In terms of job demands, the workload factor is as high as 0.47 , which is slightly lower than the factor of teaching environment $(0.58)$ and the same as the "discipline of misconduct students" in the workplace (0.47). It shows that the greatest negative factor affecting teachers' job demands is not the workload, but the sense of powerlessness facing misbehaved students and the lack of support in the work environment. The research subjects are elementary school teachers. Elementary school students are young children who are not mature enough in terms of their mental development. Those ignorant and dull children are often self-centered, have very poor self-discipline and be prone to have deviate behaviors, such as unable to keep quiet, inattentive, or distracted by their own business. Sometimes they fail to gather data for their assignment or find items requested by the teacher. Sometimes in the classroom, the class will be interrupted by quarrelling fights among students. Disorderly incidents or disciplinary acts not only cause problems for teachers, but also affect the progress of the course from time to time. In terms of teaching, teachers are always under a lot of pressure trying not to fall behind schedule, which will in turn result in poor quality of the class or tense situations in the classroom. In terms of health, constant exposure to loud noise and raising voice all the time is sure to do damage to teachers' vocal cords. If the whole situation is not improved, the noise pollution will certainly impair teachers' health, causing fatigue or physical and mental burnouts.

\section{Conflicts with parents}

Conflict is an act of confrontation and part of the interactive process. In recent years, the overall family structure has changed, the average number of children in each family has decreased, the education levels of parents are getting higher, and children' education has become the focus of parents' attention. Parents are more aware of their rights to take part in the school education. In a democratic and free society, parents are more willing than ever to express their concerns for their children's education. They stop keeping their opinions to themselves. As a result, teacher-parent conflicts are increasing with the increase of their interactions. The conflict between teachers and parents is like a land mine. It may be detonated at any time. The "parent's demand" for the teachers to function as a company with the goal of the best performance and taking responsibility to take care of children, and it is best for the teachers to act according to the parents' own ideas and standards. It seems that teachers have both students and parents as their biggest customers that demand satisfaction. Huang (2006) thinks that many educators are worried. Parents' participation in school education has become an interference with the teachers' teaching work, which has indirectly increased the occurrence of conflicts between teachers and parents. Zhan (1996) mentioned that some attitudes or concepts of both teachers and parents would ironically stand in the way 
of better interaction between them. On teachers' side, (a) they refuse to appreciate parents' participation because it is some kind of interference; (b) they have a contemptuous attitude towards parents; (c) lack of self-confidence makes them fear for parents' criticism. On parents' side, (a) they are reluctant to get involved in school activities; (b) they do not trust the school; (c) they assume the role of a bystander; (d) they do not respect teachers' autonomous profession. Parents and teachers are supposed to be partners in children' education. If they run the partnership well, they benefit each other and the children benefit the most. If the two sides do not work in harmony, the children will be the first to suffer (Single, 1997).

\section{Lack of opportunities to relax}

Teacher's participation in recreation activities has a positive impact on the improvement of teaching effectiveness. Zhang, Zhang, Lai \& Lin (2012) show that elementary teachers' satisfaction with recreation sports is a mediator impacting on teachers' work stress and job burnout. Since the implementation of two-days-off per week, everyone's view of leisure life has changed. However, teachers' work pressure has gradually increased, thanks to the education reform that emphasizes diversified teaching activities. To help relieve teacher's pressure from work, the arrangement of leisure life has become the main channel for teachers to ease their stress. It can not only reduce or lower stress, but also has the effect of relaxation and entertainment. Coleman \& Iso-Ahola (1993) also pointed out that leisure can help fight stress, reduce disease, and maintain physical as well as mental health. Moreover, at a time when pressure builds up, participation in recreation activities has a healing or diseaseprevention effect.

\section{Work resources and related research}

Work resources refer to the resources that are needed in the physical, psychological, interpersonal or organizational aspects of an employee's work. The following functions are available because of them: (1) Those that can effectively help achieve the goal of the work. (2) Those that can effectively reduce the psychological and physiological burden caused by work demands. (3) Those that can incite personal growth and development (Demerouti, Bakker, Nachreiner \& Schaufeli, 2001). Work resources may exist at the organizational level (including salary, career opportunities, job security, development possibilities, etc.), interpersonal relationships and social support (including supervisor and co-worker support, team chemistry, appreciation, recognition, etc.), in the work group (clear role positioning in the work group, chances to work with the organizational policy development team), and in the task force (performance feedback, task diversity, mission significance, importance, mission specialty, and task autonomy) (Hackman \& Oldham, 1976; 1980) are all part of the work resources. Work resources are also roughly divided into intrinsic and extrinsic resources. The former includes 
work autonomy or job function that can enhance workers' personal development and learning. The latter includes supervisor approval or support that can help employees achieve their work goals effectively. Richter \& Hacker (1998) divides the work resources into two categories: external resources, such as organizational or interpersonal relationships, social aspects; internal resources, such as personal perceptions, feelings and working styles. Chen \& Qi (2012) used the JD-R model to study how job demands and work resources impact workers' health, workers' tendency to resign, and the interrelationship among job satisfaction, attitude, and dedication. When an individual is confronted with a complicated working environment, whether he can adapt well and exert his or her ability, in addition to taking his own ability into account, the surrounding environment and external support are also important factors (Single, 1990). Reber (1995) believes that social support is the care and assistance that an individual can feel, perceive, or even actually receive from others around him. Shan (1990) believes that social support covers the concepts of "society" and "support". "Society" refers to the social environment in which individuals are connected. "Support" refers to emotional and instrumental actions of support. Thus, social support refers to emotional and instrumental support actions provided by close associates, social networks and members of the community. Cutrona (1996) argues that the definition of social support is itself based on the assumption that people must rely on each other to fulfil certain specific basic needs. He believes that the support needs are not only available in the time of crisis, but also necessary to improve the quality of life and well-being and to help adjustment in usual situations. Guralnick, Hammond, Neville \& Connor (2008) argue that there are two main sources of social support, one is informal social support sources, including family members, relatives, friends, neighbors and colleagues; the other is formal social support resources, such as service-providing professionals, government or private welfare agencies.

\section{Design of the research}

\section{Research structure}

The framework of this study as shown in Figure 1, uses the job demands-resources model to explore the psychosocial hazards and related factors in elementary school workplaces. A teacher version of COPSOQ (The Copenhagen Psychosocial Questionnaire) is used as the assessment tool (Nübling et al., 2011). In terms of job demands, quantitative demands, emotional demands, work-privacy conflicts are included. In terms of work resources, social support (supervisors, colleagues), organizational trust and fairness, work significance, leadership quality, and sense of community are included. Psychosocial hazards include noise and voice strain, lesson disturbances, conflicts with parents, lack of opportunities to relax, etc. The end result is an assessment of teachers' subjective well-being, mainly based on the scales of Renshaw, Long \& Cook (2015), which are divided into three aspects: school connectedness, teaching efficacy, and joy of teaching. 


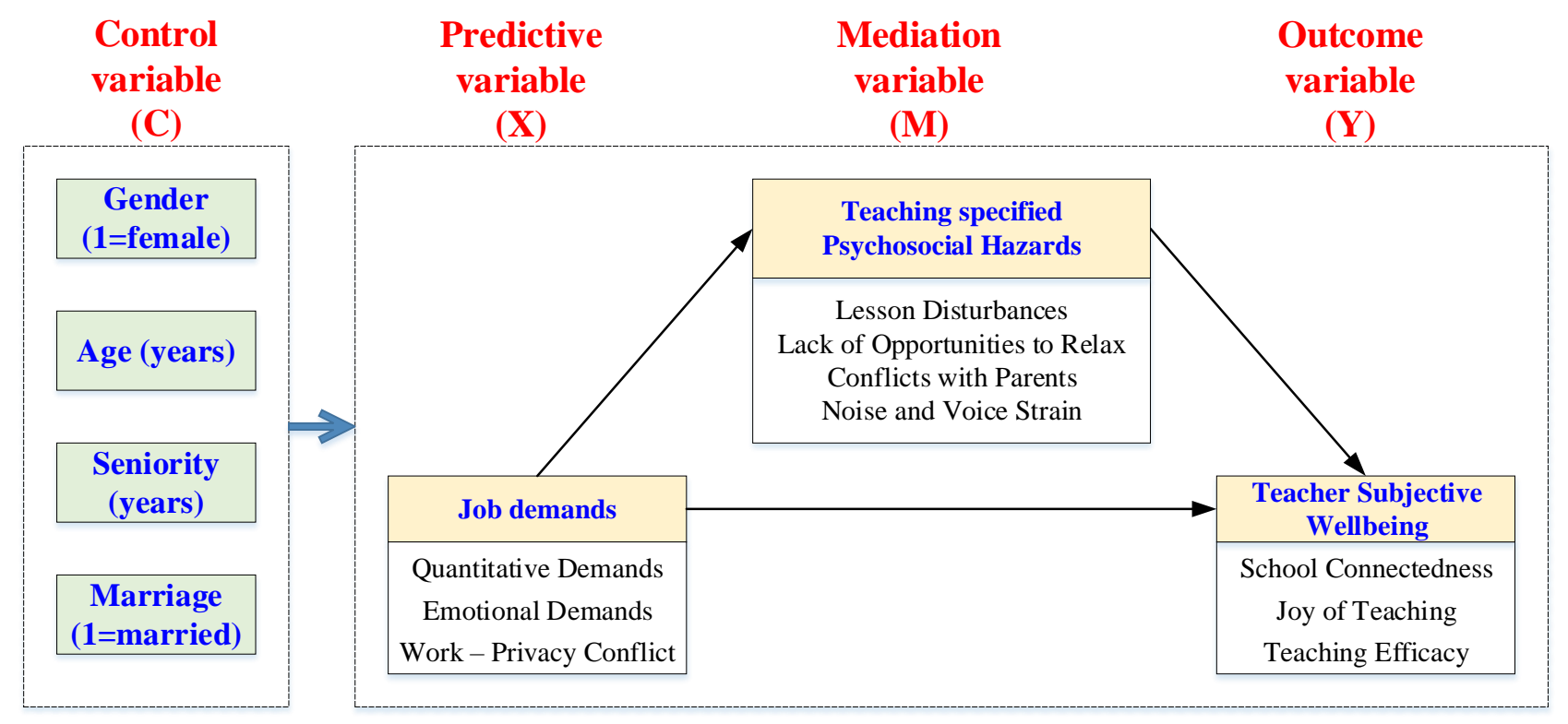

Figure 1. The diagram of impact of teaching specified psychosocial hazards and related factors on the teacher subjective wellbeing

\section{The research subjects}

The formal field survey of this study was conducted with a stratification of schools in Taiwan based on regions (North, Central, and Southern of Taiwan) and scales (large, medium, and small) by means of purposive sampling. A total of 54 primary schools were sampled, with an average of 20 teachers in each school. A total of 1,080 national teachers were surveyed. Among them, 944 valid questionnaires were returned, with an effective recovery rate of $87.41 \%$. Before the mailing of the questionnaires, subjects were contacted by mail, after an agreement with the survey was granted via telephone or email inquiry. The investigation time extended from December 1st to December 31th, 2017.

\section{Methodology}

The measurement scale was designed with reference to the related literature on psychosocial hazards and related factors (job demands-resources, teaching-related hazards) and work well-being. By integrating the items of scale development from state-of-the-arts projects, a total of 67 questions were compiled under 16 items of scales and sub-scales. The compilation is completed only after extensive discussions among the research members were held and some experts and scholars were consulted. They were consulted for their opinions and suggestions so that the amendments were finalized, thus clarifying the wording of the item names and questions.

After conducting the pre-test, in order to further verify the reliability and validity of each 
scale, the criteria of the three factors, namely, the reliability assessment (the improvement of Cronbach's $\alpha$ coefficient after the elimination of the item), the internal consistency assessment (the correlation between the corrected item and the total score), and the assessment of the decision value (the t-test of the average of the items), are first used to improve the quality of the item.

Next, factor analysis is performed to establish the construct validity of the scale. The principal components method is used for factor extraction, and the common factor with eigenvalue greater than 1 is retained, and the maximum variation method (varimax) is used to perform an orthogonal rotation, using a factor with factor loadings greater than 0.45 (Comrey $\&$ Lee, 1992). In this study, Cronbach's $\alpha$ reliability coefficient was used for reliability analysis. In most studies, Cronbach's $\alpha$ value is at least greater than 0.70 (Nunnally, 1978; George \& Mallery, 2016).

The results of the reliability and validity test of each scale of this study are shown in Table 1. The Cronbach's $\alpha$ reliability coefficient of each scale and factors is $0.768-0.947$, and the explained variance of the factors of each scale is $66.932 \%-81.097 \%$. It shows that the scales of this study have good construct validity and reliable reliability.

Table 1. Summary of the reliability and validity analysis of research tools

\begin{tabular}{lccc}
\hline \multicolumn{1}{c}{ Scale/subscale name } & $\begin{array}{c}\text { Number } \\
\text { of items }\end{array}$ & $\begin{array}{c}\text { Validity analysis } \\
\text { (Percentage of } \\
\text { explained variance, \%) }\end{array}$ & $\begin{array}{c}\text { Reliability } \\
\text { analysis } \\
\text { (Cronbach's } \alpha)\end{array}$ \\
\hline Work - Privacy Conflict & 5 & 29.019 & 0.937 \\
Emotional Demands & 5 & 19.913 & 0.804 \\
Quantitative Demands & 4 & 18.000 & 0.768 \\
\cline { 2 - 4 } Job Demands & 14 & 66.932 & 0.914 \\
\hline Noise and Voice Strain (M1) & 4 & 14.460 & 0.812 \\
Lesson Disturbances (M2) & 7 & 22.721 & 0.872 \\
Lack of Opportunities to Relax (M3) & 4 & 15.664 & 0.844 \\
Conflicts with Parents (M4) & 3 & 15.640 & 0.947 \\
\cline { 2 - 4 } Teaching specified Psychosocial Hazards & 18 & 68.485 & 0.906 \\
\hline School Connectedness & 4 & 27.133 & 0.883 \\
Joy of Teaching & 4 & 25.105 & 0.890 \\
Teaching Efficacy & 4 & 23.483 & 0.889 \\
Teacher Subjective Wellbeing & 12 & 75.720 & 0.925 \\
\hline
\end{tabular}




\section{Research results and data analysis}

\section{The sample characterization}

In this study, elementary school teachers were selected as the research subjects. A total of 944 participants were sampled in 56 schools. The average number of teachers in each school was 17 and the age of the respondents was from 22 years old to 61 years old. The average age was nearly 41 years old. Their service years are 15 on average, ranging from less than 1 year to 38 years. Table 2 shows 695 women in terms of gender, accounting for $74.25 \%$; 695 are married in terms of marital status, accounting for $74.25 \%$; 516 graduated from Master and Ph.D. programs in terms of academic status, accounting for 54.78\%; 402 people have served 15 to less than 25 years in terms of seniority level, accounting for $43.13 \%$; 430 people are 40 to 49 years old in terms of age, accounting for $45.84 \%$; the number of concurrent class tutors is 404 , accounting for $43.12 \% ; 387$ people are in a school with 48 classes or more, accounting for $41.00 \%$.

\section{The mediation effect test of teaching-related psychosocial hazards factors}

The multiple mediation effect of the social psychological hazard related to the teaching of elementary school teachers is based on the original regression coefficient to present the path coefficients. As shown in Table 2, the job demands (X), respectively, can significantly predict the noise and voice strain (M1) (a1 $=0.398, p<0.001)$, lesson disturbances (M2) (a2 $=0.359$, $p<.001)$, lack of opportunities to relax (M3) (a3=0.723, $p<.001)$, conflicts with parents (M4) (a4 $=0.384, p<.001$ ), showing that the more the teacher's perceived job demands $(\mathrm{X})$, the higher the perceived noise and voice strain (M1), lesson disturbances (M2), lack of opportunities to relax (M3), and conflicts with parents (M4).

In addition, the teaching-related psychosocial hazards that can significantly predict job well-being include lack of opportunities to relax (M3) (b3=-0.050, $p<.05)$, and conflicts with parents (M4) (b4=-0.210, $p<.001)$. When teaching-related psychosocial hazards $(\mathrm{M})$ are included, the regression coefficient of job demands $(\mathrm{X})$ on work well-being (Y) decreased, and did not reach a significant level $\left(c^{\prime}=-0.059, p>.05\right)$. Thus, the teaching-related psychosocial hazards on elementary school teachers have a complete mediation between job demands and their work well-being.

The quantification of the mediation effect is calculated using Sobel's (1982) product of coefficients $\left(\mathrm{a}^{*} \mathrm{~b}\right)$, while the mediation effect is determined by Sobel's Z-value test (Sobel, 1982) and the $95 \%$ confidence interval test of the bootstrapping resampling method (Shrout \& Bolger, 2002) to double-check whether the mediation effect is significant. 
Table 2. The mediation effect analysis of specific teaching-related psychosocial hazards in the relationship between job demands and teacher subjective wellbeing

\begin{tabular}{|c|c|c|c|c|c|c|c|c|c|c|c|c|c|c|c|c|c|}
\hline \multirow[b]{3}{*}{ Predictive variables } & \multicolumn{17}{|c|}{ Outcome variable $(\mathrm{Y})$} \\
\hline & \multicolumn{3}{|c|}{ NVS (M1) } & \multicolumn{2}{|c|}{ LD (M2) } & \multicolumn{4}{|c|}{ LOR (M3) } & & \multicolumn{3}{|c|}{ CP (M4) } & & \multicolumn{3}{|c|}{ TSW (Y) } \\
\hline & & $\mathrm{b}$ & $\mathrm{t}$ & $\mathrm{b}$ & $\mathrm{t}$ & & & $\mathrm{b}$ & $\mathrm{t}$ & & & $\mathrm{b}$ & $\mathrm{t}$ & & & $\mathrm{b}$ & $\mathrm{t}$ \\
\hline Intercept & iM1 & 1.904 & $8.368 * * *$ iM2 & 2.247 & 11.241 & $* * *$ & iM3 & 1.000 & 4.494 & $* * *$ & iм4 & 1.375 & 6.367 & $* * *$ & iy & 4.489 & $27.990 * * *$ \\
\hline Gender (1=female) & & 0.047 & 0.846 & 0.004 & 0.091 & & & 0.254 & 4.723 & $* * *$ & & -0.136 & -2.602 & & & 0.056 & 1.515 \\
\hline Age (years) & & -0.008 & -1.270 & -0.009 & -1.796 & & & -0.015 & -2.532 & & & -0.002 & -0.339 & & & 0.007 & 1.893 \\
\hline Seniority (years) & & 0.001 & 0.161 & 0.001 & 0.162 & & & 0.017 & 3.055 & $* *$ & & -0.002 & -0.286 & & & -0.007 & $-2.037 *$ \\
\hline Marriage $(1=$ married $)$ & & -0.020 & -0.315 & 0.081 & 1.489 & & & 0.101 & 1.673 & & & -0.062 & -1.051 & & & 0.051 & 1.242 \\
\hline Job Demand $(\mathrm{X})$ & a1 & 0.398 & $10.268 * * *$ a2 & 0.359 & 10.565 & $* * *$ & a3 & 0.723 & 19.109 & $* * *$ & $\mathrm{a} 4$ & 0.384 & 10.467 & $* * *$ & $\mathrm{c}^{\prime}$ & -0.059 & -1.898 \\
\hline NVS (M1) & & --- & --- & --- & --- & --- & & --- & --- & --- & & --- & --- & --- & $\mathrm{b} 1$ & -0.039 & -1.540 \\
\hline LD (M2) & & --- & --- & --- & --- & --- & & --- & --- & --- & & --- & --- & --- & b2 & -0.055 & -1.767 \\
\hline LOR (M3) & & --- & --- & --- & --- & --- & & --- & --- & --- & & --- & --- & --- & b3 & -0.050 & $-2.001 *$ \\
\hline CP (M4) & & --- & --- & --- & --- & --- & & --- & --- & --- & & --- & --- & --- & b4 & -0.210 & $-8.418 * * *$ \\
\hline Explained & & $\mathrm{R}^{2}=$ & $11.04 \%$ & $\mathrm{R}^{2}=1$ & $11.83 \%$ & & & $\mathrm{R}^{2}=$ & $31.36 \%$ & & & $\mathrm{R}^{2}=$ & $11.64 \%$ & & & $\mathrm{R}^{2}=$ & $19.66 \%$ \\
\hline Variance $(\%)$ & $\mathrm{F}(5$, & $898)=2$ & 22.286 *** $\mathrm{F}(5$ & $, 898)=2$ & 24.105 & $* * *$ & & $, 898)=$ & 82.047 & $* * *$ & & $898)=$ & 23.660 & $* * *$ & & $, 894)=$ & $24.312 * * *$ \\
\hline
\end{tabular}

$* \mathrm{p}<.05, * * \mathrm{p}<.01, * * * \mathrm{p}<.001 ; \mathrm{n}=904 ; \mathrm{b}$ is unstandardized regression coefficient

Note: NVS - Noise and Voice Strain; LD - Lesson Disturbances; LOR - Lack of Opportunities to Relax; CP - Conflicts with Parents; TSW - Teacher Subjective Wellbeing 
As shown in Table 3, the results of the mediation effect test showed that there was a significant $(p<.05)$ indirect effect between the lack of opportunities to relax (M3) and conflicts with parents (M4); and the strength of mediation $\mathrm{SM}=\mathrm{a} * \mathrm{~b} / \mathrm{c}$ (Shrout \& Bolger, 2002) is not significant, $17.29 \%$ for the lack of opportunities to relax (M3) and 38.82\% for conflicts with parents (M4). As shown in Fig. 2, the standardized regression coefficients are presented to compare the relative importance of each path. The dotted line in the figure shows that there is no significant impact. The solid line shows that a significant impact is there. And the thick solid line shows the strongest mediation effect. They lead us to believe that elementary school teachers' job demands $(\mathrm{X})$ have a positive impact on or increase two of the teaching-related psychosocial hazards, namely, lack of opportunities to relax (M3) and conflicts with parents (M4). As a result, their well-being at work is significantly reduced.

Table 3. Summary of the mediation effect analysis of teaching specified psychosocial hazards

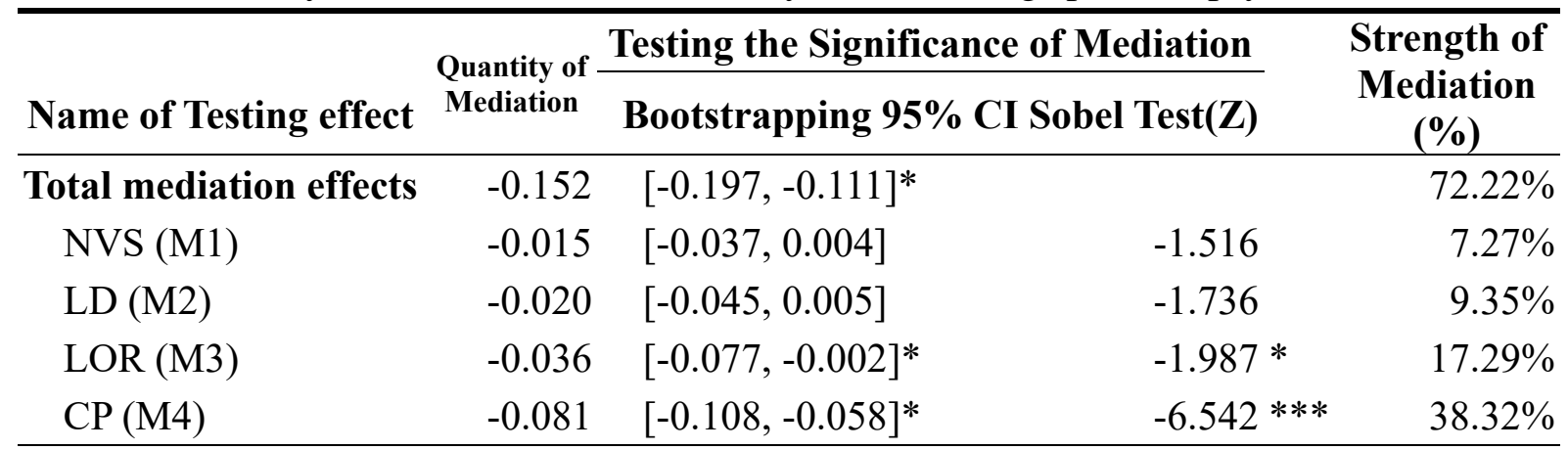

Comparison of tests of mediation effect

\begin{tabular}{lll} 
M1-M2 & 0.004 & {$[-0.030,0.038]$} \\
M1-M3 & 0.021 & {$[-0.022,0.064]$} \\
M1-M4 & 0.066 & {$[0.033,0.101]^{*}$} \\
M2-M3 & 0.017 & {$[-0.033,0.070]$} \\
M2-M4 & 0.061 & {$[0.025,0.100]^{*}$} \\
M3-M4 & 0.044 & {$[-0.002,0.089]$} \\
\hline
\end{tabular}

$* \mathrm{p}<.05, * * \mathrm{p}<.01, * * * \mathrm{p}<.001$

Note: NVS - Noise and Voice Strain; LD - Lesson Disturbances; LOR - Lack of Opportunities to Relax; CP - Conflicts with Parents

Finally, the results of the difference in the mediation effects of the four teaching-related psychosocial hazards show that the mediation effect of conflicts with parents (M4) is significantly higher than that of lesson disturbances (M2) and noise and voice strain (M1) in the relationship between job demands and job satisfaction. It can be seen that, between the job demands of the elementary school teachers $(\mathrm{X})$ and their work well-being $(\mathrm{Y})$, the conflicts with parents (M4) has a significantly higher mediation effect among the four kinds of teachingrelated psychosocial hazards. That is, the more job demands $(\mathrm{X})$ the elementary school teachers have, the more conflicts with parents (M4) they would experience and thus the lower work 
well-being (Y) they feel.

Control

variable

(C)

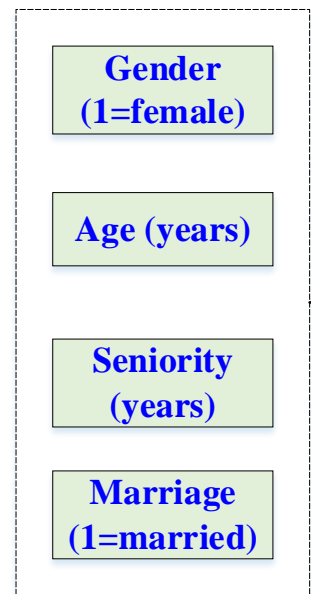

\section{Predictive variable}

(X)

\author{
Mediation \\ variable
}

(M)
Outcome

variable

(Y)

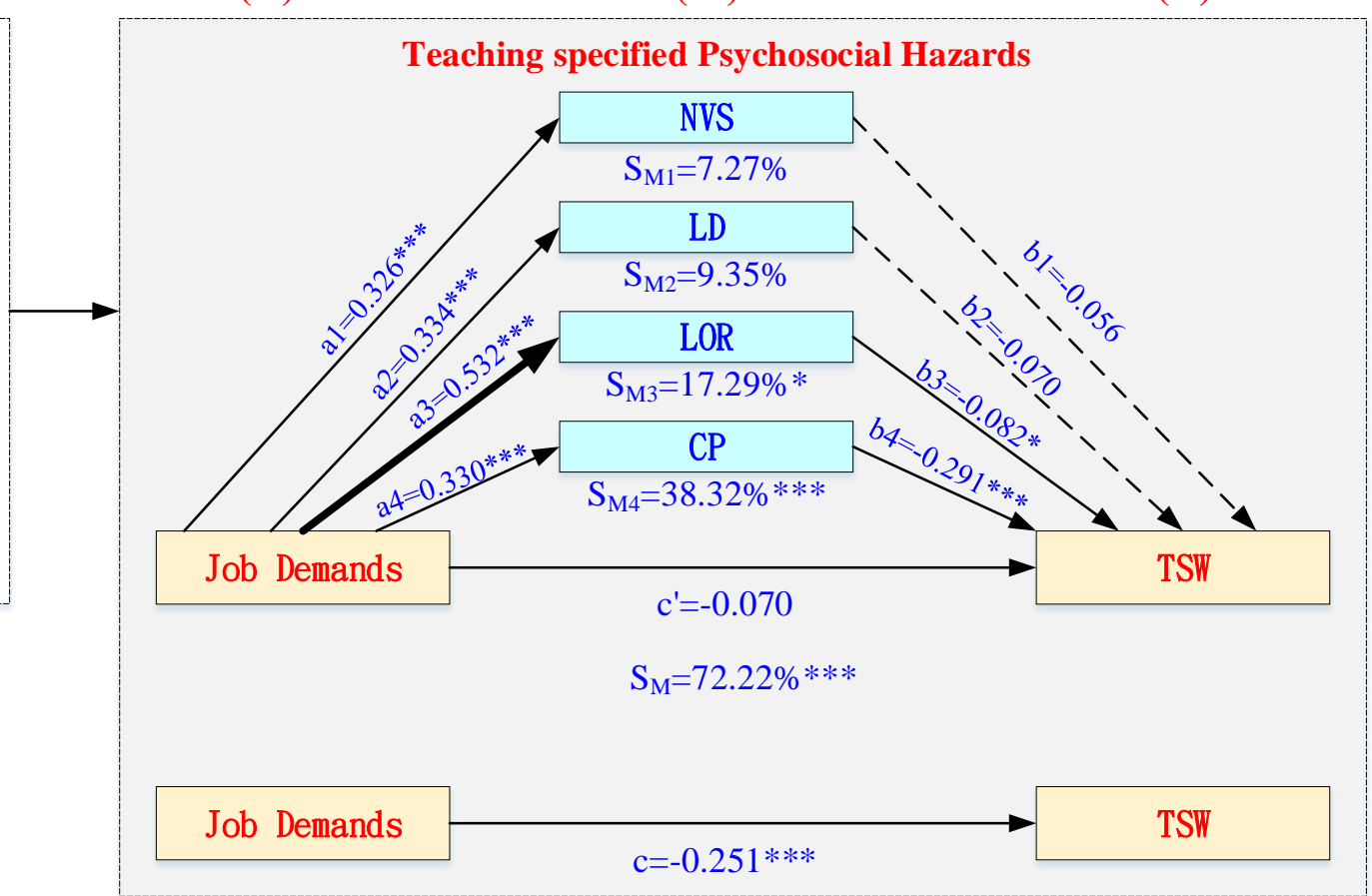

Figure 2. The diagram of multiple mediation effects of the teaching specified psychosocial hazards

Note: ${ }^{*} p<.05,{ }^{* *} p<.01, * * * p<.001 ; \mathrm{n}=904 ; \mathrm{a}, \mathrm{b}, \mathrm{c}$ are standardized regression coefficient NVS - Noise and Voice Strain; LD - Lesson Disturbances; LOR - Lack of Opportunities to Relax; CP - Conflicts with Parents; TSW - Teacher Subjective Wellbeing

\section{Conclusion and Recommendations}

\section{Conclusion}

The analysis results show that the mediation intensity of teaching-related psychosocial hazards is $72 \%$, while the facets of the teaching-related psychosocial hazards have a significant weakening mediation effect on the positive relationship between work resources and work wellbeing, showing only a low mediation strength of $14 \%$. It shows that more teachers are aware that the more job demands they are required to meet, the more teaching-related psychosocial hazards (including noise and voice strain, lesson disturbances, lack of opportunities to relax, conflicts with parents) they would endure. It also shows that the facets of the teaching-related psychosocial hazards have a significantly deteriorating mediation effect on the negative relationship between job demands and work well-being (with a mediation intensity of $72 \%$ ). Among them, only the lack of opportunities to relax (with a mediation intensity of 17\%) and 
the conflicts with parents (with a mediation intensity of 38\%) have more significant mediation effects. The more work resources elementary school teachers are aware of, the better they can significantly reduce teaching-related psychosocial hazards (including noise and voice strain, lesson disturbances, lack of opportunities to relax, conflicts with parents); teaching-related psychosocial hazards have a significantly weakening mediation effect on the positive relationship between work resources and work well-being (with a mediation intensity of 14\%). Among them, only lesson disturbances (with a mediation intensity of $4 \%$ ) and conflicts with parents (with a mediation intensity of $10 \%$ ) have some mediation effects.

\section{Recommendations}

Suggestions on school's daily practice

Promoting teachers' appreciation of meaning in work and the sense of community to enhance their work well-being

The results of this study show that the teachers' perception of the work and the sense of community can significantly affect their work well-being. Therefore, it is recommended that elementary schools can do a good job in planning all their work, so that every teacher would think that the work as a teacher is meaningful and that he or she is doing something important and worthy of earnest zeal and full commitment. Schools should create a good atmosphere for teachers to get along with one another, have good experience in working with colleagues and feel that they are members of the school community and belong to the big family.

Establishing a response strategy and support system for the emotional demands of elementary school teachers

The results of this study show that the most influential factor in job demands is the emotional demands. In other words, the more emotional demands are to be imposed on elementary school teachers, the more likely their work well-being will be significantly reduced. Every school needs to help teachers learn how to cope with a variety of emotional demands and how they can deal with them. For example, the work will make them emotionally disturbed, the work will have more attention and emotional demands, the work would demand them emotionally involved, the work would require them to hide their emotion and feeing, or the work might require them to keep their opinions to themselves.

Moreover, schools should establish support systems to reduce the emotional labor on teachers. Senior teachers have much more experience in the society, are familiar with the environments inside and outside of the school, and know how to communicate well with parents. However, because they are new comers to the education world, junior teachers not 
only need time to familiarize themselves with the school environment, parents are also suspicious about their ability. The emotional labor of junior teachers is too heavy, which leads to loss of their enthusiasm in teaching. Therefore, it is recommended that schools should assign both senior teachers and new teachers to teach students of every grade with balanced distribution so that senior teachers can support new teachers at any time. New teachers are encouraged to learn through dialogue and consultation from senior teachers how to prepare class materials and learn about teaching methods and how to better their communication with parents. The main purpose of the experience-sharing sessions is to help new teachers to uphold their zeal at work and create a better atmosphere for all teachers of the same school.

Providing more working resources for elementary school teachers and bolstering multiple channels for better communication

This study found that the more elementary school teachers are aware of work resources (such as organizational trust and fairness, work significance, leadership quality, sense of community), the better they can improve their work well-being. Teachers are the first-line educators responsible for classroom teaching and student guidance. They play the key role in shouldering up the responsibility for the success and failure of students' education. It is therefore very important for the school leadership to better communication channels with teachers and encourage teachers in a timely manner, such as praising and recommending good teachers in the public whenever they can, so that they will feel trusted and appreciated. It is also important for the schools to construct a supportive education system to help teachers solve their problems in teaching so that they would feel honorable to share ups and downs of the school as a family. Gradually, the school's administration and the organization will have teachers' trust. Teachers would then believe that they are fairly treated and they have enough work resources to help them achieve better work well-being.

\section{Suggestions for teachers in teaching}

Elementary school teachers should be more engaged in stress-easing activities and seek appropriate channels for relief

With continuous introduction of the new education policies, relevant policies are constantly updated and adjusted to support the new ones. As the front-line educators, teachers are under unprecedented pressure to keep abreast of the new development. The study found that factor of "lack of opportunities to relax" in teaching-related psychosocial hazards can negatively affect their work well-being significantly. Therefore, teachers should find time to relieve their stress built up from work because they can bring happiness to students when they are happy themselves. So how to manage their time well and make plans to relax is something teachers need to learn at a time of great pressure. For example, they should find 
piecemeal time from tight schedule to enrich their knowledge and skills, make it a habit to exercise regularly, and arrange recreation activities to ease their stress. If they take care of their body and mind well, their students will benefit most from their sound health. It is recommended that schools can set aside a comfortable lounge or relaxing area for teachers, so that teachers can get away from the noisy classrooms temporarily. It is also recommended that teachers should force themselves to take the short break to move around or have a cup of tea. They can even decorate the classroom with posted reminders or potted plants or ornaments, with a view to distracting themselves from tedious teaching routines.

Elementary school teachers should continue to improve their class management and communication skills

This study found that school teachers are aware that, among teaching-related psychosocial hazards, lesson disturbances and conflicts with parents are highly hazardous to their work well-being. In the classroom, teachers are expected to face a variety of classroom disturbances every day. For example, some students are busy with other things and interfere with classroom activities. Some students are not well prepared to achieve the goals they are supposed to achieve. Or there is no enough time in the class to extend the goals of the class. Some students are not attentive to what happens in the class. Or the teacher is forced to discipline students from time to time. For some unexpected incidents, there might not be enough time to take care of. And the noise and turbulence from students are expected all the time. Then conflicts with parents can also be hazardous. For example, parents criticize teachers' teaching work, parents challenge teachers' professional judgment and parents even make personal criticism against the teacher with no reasonable causes. Thus, it is recommended that teachers participate in workshops of class management, student discipline, and how to communicate with parents, so that teachers can learn how to deal with lesson disturbances and conflicts with parents better.

\section{Suggestions for future research}

\section{To extend research to cover different levels and different variables}

It is suggested that follow-up studies can be extended to cover variables of teacher's personal traits, such as self-efficacy, resilience, positive mental capital, group-level variables, such as interpersonal relationships, team unity, community sharing, and organizational level variables, such as leadership style, school culture, organizational support, and other factors so as to explore more comprehensively the impacts of different levels of psychosocial hazards and related factors on teachers' physical and mental health.

To investigate the differences for different age groups and genders 
Different responses may be possible if the research is conducted with different age groups or genders. It is suggested that the follow-up study can divide the elementary school teachers into three groups of teachers who are responsible for low, middle and high graders, or explore the differences in teacher perceptions by considering different genders.

\section{To strengthen the depth and breadth of statistical analysis}

It is suggested that the follow-up study can use the job demands-resources mode to modify the effect analysis or the mediation effect analysis with a combination of different variables. Also, the Covariance Based Structural Equation Modeling (CB-SEM) or the Partial Least Squares Based Structural Equation Modeling (PLS-SEM) can be used to construct a model to verify or explore how teaching-related psychosocial hazards and related factors would impact elementary school teachers' work well-being or physical and mental health outcomes.

\section{References}

Al-Ghamdi, N. G. (2017), "Role Overload and Job Stress among the Female University Teachers- Saudi Context”, European Online Journal of Natural and Social Sciences, Vol. 6 No. 2, pp. 288-295.

Al-Qutop, M. Y., \& Harrim, H. (2011), “Quality of work-life human well-being linkage: Integrated conceptual framework", International Journal of Business and Management, Vol. 6 No. 8, pp. 193-205.

Bakker, A. B., Demerouti, E., \& Euwema, M. C. (2005), "Job resources buffer the impact of job demands on burnout", Journal of Occupational Health Psychology, Vol. 10 No. 2, pp. 170-180.

Başol, G. \& Altay, M. (2009), "Examining occupational burnout levels of educational administrators and teachers", Educational Administration: Theory and Practice, Vol. 15 No. 58, pp. 191-216.

Kırılmaz, A. Y., Çelen, Ü. \& Sarp, N. (2003), “A study on teacher burnout with a group of primary school teachers", Ilkogretim-Online, 2 No. 1, pp. 2-9. http://ilkogretimonline.org.tr/vol2say1/v02s01a.pdf

Baumgardner, S. R., Crothers, M. K. (2009), "Positive psychology”, Upper Saddle River, NJ: Prentice-Hall.

Bricheno, P., Brown, S., \& Lubansky, R. (2009), “Teacher Wellbeing: A review of the evidence”, London: Teacher Support Network Services.

Carruthers, C. P., \& Hood, C. D. (2004), “The power of the positive: Leisure and well-being”, Therapeutic Recreation Journal, Vol. 38 No. 2, pp. 225-245.

Chen, Y., \& Wu C. H. (2004), “Analysis of the impact of school building patterns on noise levels", The second edition of the 2004 Symposium on Resources and Environmental Management, pp. 7-1 7-12. 
Çokluk, Ö. (2003), “Modern approaches, applications and problems in administration”, İçinde, Ankara: Ani Yayincilik.

Coleman, D., \& Iso-Ahola, S. E. (1993), "Leisure and health: the role of social support and self-determination”, Journal of leisure research, Vol. 25 No. 2, pp.111-128.

Comrey, A., \& Lee, H. (1992), “A first course in factor analysis. Hillsdale, New Jersey: Erlbaum.

Cooper, C. L., Dewe, P. J., \& O’Driscoll, M. P. (2001), “Organizational stress: A review and critique of theory, research, and applications", Thousand Oaks, CA: Sage.

Cordes, C. L., \& Dougherty, T. W. (1993), “A review and an integration of research on job burnout", Academy of Management Review, Vol. 18 No. 4, pp.621-656. doi:10.5465/AMR.1993.9402210153

Cutrona, C. E. (1996), "Social support in couples; Marriage as a resource in times of stress", Thousand Oaks. CA: Sage.

Dai, X. H., \& He, R. T. (2006), “A study on the relationship between work stress and job satisfaction of the physical education teachers in Taipei County", Southeast Journal, Vol. 30, pp. 309-320.

Demerouti, E., Bakker, A. B., Nachreiner, F., \& Schaufeli, W. B. (2001), “The job demandsresources model of burnout”, Journal of Applied Psychology, Vol. 86 No. 3, pp. 499-512.

Demerouti, E., Bakker, A. B., Nachreiner, F., \& Schaufeli, W. B. (2000), “A model of burnout and life satisfaction amongst nurses", Journal of Advanced Nursing, Vol. 32 No. 2 , pp.454-464.

Diener, E. (1984), “Subjective well-being. Psychological Bulletin”, Vol. 95 No. 3, pp. 542575.

Diener, E., Lucas, R. E., \& Oishi, S. (2005), “Subjective Well-Being: The Science of Happiness and Life Satisfaction", In C. R. Snyder, \& S. J. Lopez (Eds.), Handbook of Positive Psychology (2 ${ }^{\text {nd }}$ Ed., pp. 63-73), New York, NY: Oxford University Press.

Dong, W. (2001), "School noise is related to teacher-teaching volume, voice health, and changes in auditory signs", Journal of Health Education, Vol. 14, pp. 113-136.

Eschricht, D., Greschner, B., Thiele, F., \& Jacob, M.C. (2009), "Numerical Simulation of Jet Mixing Noise Associated with Engine Exhausts", Notes on Numerical Fluid Mechanics and Multidisciplinary Design, Vol. 104, pp. 121-146.

George, D., \& Mallery, P. (2016), “IBM SPSS statistics 23 step by step: A simple guide and reference ( $14^{\text {th }} E d$.)", New York, NY: Routledge Taylor \& Francis Group.

Grandey, A. A. (2000), "Emotion regulation in the workplace: a new way to conceptualize emotional labor", Journal of Occupational Health Psychology, Vol. 5 No. 1, pp. 95-110.

Green, F., Felstead, A., Gallie, D., \& Inanc, H. (2013), “Job-Related Wellbeing in Britain: First Findings from the Skills and Employment Survey 2012”, London: Center for learning and life chances in knowledge economics and society, institute of education. Project Report (London: Centre for Learning and Life Chances in Knowledge Economies and Societies, Institute of Education). 
Guo, M. T. (2005), “The impact of noise on attention and cognition”, Jianan Pharmaceutical Science and Technology University special research project report. Retrieved from the Internet http://ir.cnu.edu.tw/bitstream/310902800/918/1/93CNOS9302_2.pdf

Guralnick, M. J., Neville, B., Hammond, M. A., Connor, R. T., \& Abbeduto, L. (2008), "Mothers' social communicative adjustments to young children with mild developmental delays", American Journal on Mental Retardation, Vol. 113 No. 1, pp. 1-18.

Hackman, J. R., \& Oldham, G. R. (1976), "Motivation through the design of work: test of a theory", Organization behavior and human performance, Vol. 16, pp. 250-279.

Hackman, J. R., \& Oldham, G. R. (1980), “Work redesign”, MA: Addison-Wesley.

Hakanen, J. J., Bakker, A. B., \& Schaufeli, W. B. (2006), "Burnout and work engagement among teachers", Journal of School Psychology, Vol. 43 No. 6, pp. 495-513.

Hayes, A. F. (2018), “Introduction to Mediation, Moderation, and Conditional Process Analysis”, New York, NY: Guilford Publications, Inc.

Hean, S., \& Garrett, R. (2001), "Sources of job satisfaction in science secondary school teachers in Chile", Compare: A Journal of Comparative Education, Vol. 31 No. 3, pp. 363-379.

Hochschild, A. R. (1993), "Preface”, In S. Fineman (Ed.), Emotion in organizations (pp. 3657), London: Sage.

Hochschild, A. R., (1983), “The managed heart: Commercialization of human feeling”, Berkeley: University of California.

Huang, Y. W. (2006), "How does the school survive in the cracks of the conflict between teachers and teachers - explore the causes, functions and responses of conflicts", School Administration Bimonthly, Vol. 45, pp. 226-236.

Ilgan, A., Özü-Cengiz, Ö., Ata, A., \& Akram, M. (2015), “The relationship between teachers' psychological well-being and their quality of school work life", The Journal of Happiness \& Well-Being, Vol. 3 No. 2, pp. 159-181.

International Labor Organization (2000), "Mental Health in the Workplace”, Geneva: ILO.

Kaempf, S., \& Krause, A. (2004), "Risk assessment for the analysis of psychological workload in the working place school", (German: Gefährdungsbeurteilungen zur Analyse psychischer Belastungen am Arbeitsort Schule.) In: Bungard W, Koop B, Liebig C (Eds), Psychologie und Wirtschaft leben - Aktuelle Themen der Wirtschaftspsychologie in Forschung und Praxis. München: Rainer Hampp, pp. 314-319.

Ke, Y. X., Lin, J. G. (2006), “A Study on the Relationship between Work Stress and Burnout of High School Dance Teachers - Taking the Public High School Dance Class in Taiwan as an Example", Art Journal, Vol. 79, pp. 231-251.

Keyes, C. L. M., \& Magyar-Moe, J. L. (2003), “The measurement and utility of adult subjective well-being”, In S. J. Lopez \& C. R. Snyder (Eds.), Positive psychology assessment: A handbook of models and measures (pp. 411-425). Washington, DC: American Psychological Association.

Keyes, C. L., Shmotkin, D., \& Ryff, C. D. (2002), “Optimizing well-being: The empirical 
encounter of two traditions", Journal of Personality and Social Psychology, Vol. 82 No.

6, pp. 1007-1022.

Kyriacou, C. (2001), “Teacher stress: Directions for future research”, Educational Review,

Vol. 53 No. 1, pp. 27-35.

Labor and Occupational Safety and Health Research Institute of the Ministry of Labor (2011), “Cognitive Survey on Work Environment Safety and Health Status - 2010”, The 99-year research project IOSH99-M306.

Lai, W. J. (2005), "A Probe into the Psychological Happiness of Primary and Secondary School Teachers in Taiwan: Comparison with Other Occupations", Taiwan Educational Sociology Research, Vol. 5 No. 1, pp. 159-195.

Lee, R. T., \& Ashforth, B. E. (1996), "A meta-analytic examination of the correlates of the three dimensions of job burnout", Journal of Applied Psychology, Vol. 81 No. 2, pp. 123 133.

Li, J. Q., Chen, J. Y., \& Chen, J. L. (2006), "Healthy workplace: the application of stress risk management", Industrial Safety Technology, Vol. 58, pp. 11-16.

Li, X. M., \& Chen, M. T. (2006), “The structure of emotional labor factors of preschool teachers and its impact on job burnout", Journal of Kaohsiung Normal University: Education and Social Sciences, Vol. 20, pp. 67-89.

Ministry of Education (2012), "White Paper on Teacher Education in the Republic of China”, Retrieved from http://ws.moe.edu.tw/001/Upload/3/RelFile/6315/6921/Traditional Chinese Teacher Education White Paper.pdf

Mulholland, R., McKinlay, A., \& Sproule, J. (2013), “Teacher Interrupted: Work Stress, Strain, and Teaching Role. SAGE Open, pp. 1-13.

Näring, G., Briët, M., \& Brouwers, A. (2006), "Beyond demand-control: Emotional labour and symptoms of burnout in teachers", Work \& Stress, Vol. 20 No. 4, pp. 303-315.

Nübling, M., Vomstein, M., Haug, A., Nübling, T., \& Adiwidjaja, A. (2011), “European-Wide Survey on Teachers Work Related Stress - Assessment, Comparison and Evaluation of the Impact of Psychosocial Hazards on Teachers at their Workplace”, FFAS: Freiburg research center occupational and social medicine, Germany.

Nübling, M., Wirtz, M., Neuner, R., \& Krause, A. (2008), “Measuring psychological stress among teachers", Development of an instrument for the census-survey in BadenWürttemberg. (German: Ermittlung psychischer Belastungen bei Lehrkräften.

Entwicklung eines Instruments für die Vollerhebung in Baden- Württemberg). Zbl Arbeitsmed, Vol. 58, pp. 312-313. Access form http://schule-copsoq.de/data/COPSOQZentralblatt-Arbeitsmedizin-Oktober-2008.pdf.

Nunnally, J. C. (1978), "Psychometric theory (2 ${ }^{\text {nd }}$ Ed.)", New York, NY: McGraw-Hill. Reber, S. (1995), "Dictionary of psychology”, New York: Penguin.

Renshaw, T. L., Long, A. C., \& Cook, C. R. (2015), “Assessing teachers’ positive psychological functioning at work: Development and validation of the teacher subjective wellbeing questionnaire”, School Psychology Quarterly, Vol. 30 No. 2, pp. 289-306. 
Richter, P., \& Hacker, W. (1998), “Workload and strain: Stress, fatigue, and burnout in working life”, Germany: Asagner.

Romano, J. L., \& Wahlstrom, K. (2000), "Professional stress and well-being of K-12 teachers in alternative educational settings: A leadership agenda", International Journal of Leadership in Education, Vol. 3 No. 2, pp. 121-135.

Sandiford, P. J., \& Seymour, D. (2002), "Emotional labor in public houses: Reflections on a pilot study”, Journal of Hospitality \& Tourism Research, Vol. 26 No. 1, pp. 54-70.

Sarath, P., \& Manikandan, K. (2014), "Work engagement and work related wellbeing of school teachers”, Selp Journal of Social Science, Vol. 5 No. 22, pp. 93-100.

Shan, X. L. (1990), "Discussion on teachers' social support and related factors", Journal of Taipei City Teachers College, Vol. 21, pp. 123-154.

Shan, X. L. (1997), "Don't be angry with the teacher's parents", Taipei: United Economics.

Shrout, P. E., \& Bolger, N. (2002), "Mediation in experimental and non-experimental studies: New procedures and recommendations", Psychological Methods, Vol. 7, pp. 422- 445.

Sobel, M. E. (1982), “Asymptotic intervals for indirect effects in structural equations models”, In S. Leinhart (Ed.), Sociological methodology 1982 (pp. 290-312). San Francisco: Jossey-Bass.

Wilson, W. (1967), "Correlates of avowed happiness”, Psychological Bulletin, Vol. 67 No. 4 , pp. 294-306.

Wu Z. Y., \& Zheng, B. Z. (2003), "Review and prospect of organizational emotion research", Applied Psychological Research, Vol. 19, pp. 137-173.

Yildirim, K. (2015), “Testing the main determinants of teachers' professional well-being by using a mixed method", Teacher Development, Vol. 19 No. 1, pp. 59-78.

Zhan, Z. W. (1996), "Family and school - blame, division of labor or cooperation", North County Education, Vol. 11, pp. 8-11.

Zhang, Z. M., Zhang, Y. Z., Lai, Y. Z., \& Lin, X. C. (2012), “The mediation effect of leisure sports satisfaction of small and medium-sized teachers in work stress and job burnout", Management Practice and Theoretical Research, Vol. 6 No. 1, pp. 82-98.

Zhou, Z. J., \& Peng, Y. Q. (2005), “Domestic college teachers' work pressure and job satisfaction model”, Journal of Educational Psychology, Vol. 36 No. 3, pp. 201-219. 